\title{
a2-containing $\mathrm{GABA}_{\mathrm{A}}$ receptors: A target for the development of novel treatment strategies for CNS disorders
}

\author{
Elif Engin, Jing Liu, and Uwe Rudolph \\ Laboratory of Genetic Neuropharmacology, McLean Hospital, Belmont, MA 02478, and \\ Department of Psychiatry, Harvard Medical School, Boston, MA
}

\begin{abstract}
$\mathrm{GABA}_{\mathrm{A}}$ receptors have important physiological functions, as revealed by pharmacological studies and experiments involving gene-targeted mouse models, and are the target of widely used drugs such as the benzodiazepines. In this review, we are summarizing current knowledge about the function of a 2 -containing $\mathrm{GABA}_{\mathrm{A}}$ receptors, a receptor subtype representing approximately 15$20 \%$ of all $\mathrm{GABA}_{\mathrm{A}}$ receptors. This receptor subtype mediates anxiolytic-like, reward-enhancing, and antihyperalgesic actions of diazepam, and has antidepressant-like properties. Secondary insufficiency of a2-containing $\mathrm{GABA}_{\mathrm{A}}$ receptors has been postulated to play a role in the pathogenesis of schizophrenia, and may be involved in cognitive impairment in other disorders. Moreover, polymorphisms in the GABRA2 gene encoding the $\mathrm{GABA}_{\mathrm{A}}$ receptor a 2 subunit have been found to be linked to chronic alcohol dependence and to polydrug abuse. Thus, a2containing $\mathrm{GABA}_{\mathrm{A}}$ receptors are involved in the regulation and/or modulation of emotional behaviors and of chronic pain, and appear to be a valid target for novel therapeutic approaches for the treatment of anxiety, depression, schizophrenia and chronic pain.
\end{abstract}

\section{Keywords}

$\mathrm{GABA}_{\mathrm{A}}$ receptor; benzodiazepines; anxiety; depression; chronic pain; schizophrenia

\section{Introduction}

$\gamma$-aminobutyric acid (GABA) is the major inhibitory neurotransmitter in the central nervous system (CNS). GABAergic inhibition is essential for temporal modulation and maintenance of the excitation/inhibition balance and for the entrainment of oscillatory activities (Klausberger \& Somogyi, 2008). GABA acts at ionotropic $\mathrm{GABA}_{\mathrm{A}}$ receptors and at metabotropic $\mathrm{GABA}_{\mathrm{B}}$ receptors.

$\mathrm{GABA}_{\mathrm{A}}$ receptors are formed as pentameric combinations of homologous subunits. There are 19 genes known encoding $\mathrm{GABA}_{\mathrm{A}}$ receptor subunits $(\alpha 1-6, \beta 1-3, \gamma 1-3, \delta, \varepsilon, \theta, \pi, \rho 1-$

() 2012 Elsevier Inc. All rights reserved.

Address for correspondence: Uwe Rudolph, Laboratory of Genetic Neuropharmacology, McLean Hospital, Room MRC123A, Harvard Medical School, 115 Mill Street, Belmont, MA 02478, USA, Phone 001-617-855-2088, Fax 001-617-855-2012, urudolph@mclean.harvard.edu.

Publisher's Disclaimer: This is a PDF file of an unedited manuscript that has been accepted for publication. As a service to our customers we are providing this early version of the manuscript. The manuscript will undergo copyediting, typesetting, and review of the resulting proof before it is published in its final citable form. Please note that during the production process errors may be discovered which could affect the content, and all legal disclaimers that apply to the journal pertain.

Conflict of Interest Statement:

"In the last three years, UR has provided professional services for Sunovion and for Concert Pharmaceuticals. JL and EE declare that they have no conflict of interest." 
3) (Olsen \& Sieghart, 2008), with receptors formed by $a, \beta$ and $\gamma$ subunits being the most common. The a subunits provide the largest diversity, and for practical purposes $\mathrm{GABA}_{\mathrm{A}}$ receptors are most frequently classified by their a subunits.

This diverse set of receptors are the targets of a variety of therapeutically useful CNS-active compounds, e.g. benzodiazepines, zolpidem, zopiclone, barbiturates, etomidate, propofol, and neurosteroids (Rudolph \& Antkowiak, 2004; Rudolph \& Knoflach, 2011). Out of these compounds, benzodiazepines have been the most extensively studied, largely due to their widespread clinical use in the treatment of anxiety disorders. Benzodizepines are positive allosteric modulators (PAM) of the $\mathrm{GABA}_{\mathrm{A}}$ receptors, with a variety of actions, including sedation, hypnosis, muscle relaxation, and anticonvulsant and amnestic effects, in addition to anxiolysis. This wide array of behavioral effects reduces the therapeutic utility of clinically used benzodiazepines (e.g., diazepam, chlordiazepoxide, midazolam), as even when they are effective in reaching the desired therapeutic targets (e.g., anxiolysis in patients with anxiety disorders), they are associated with a number of unwanted side effects (e.g., sedation and hypnosis). Thus, understanding the molecular substrates for each of these behavioral endpoints has been a major research interest with the hope of producing more therapeutically-specific GABAergic compounds in the future. Differential quantitative and anatomical distribution of $\mathrm{GABA}_{\mathrm{A}}$ receptor subunits in the CNS, and differential modulation by benzodiazepines of different $\mathrm{GABA}_{\mathrm{A}}$ receptors based on subunit composition provided the first clues in terms of an understanding of benzodiazepine behavioral pharmacology.

Whereas the GABA binding sites on $\mathrm{GABA}_{\mathrm{A}}$ receptors are formed by residues on the $\mathrm{a}$ and $\beta$ subunits, the binding sites for benzodiazepines are formed by residues on $a$ and $\gamma$ subunits (Sigel \& Luscher, 2011). Benzodiazepines bind to $\mathrm{GABA}_{\mathrm{A}}$ receptors containing the a 1, $\mathrm{a} 2$, $a 3$, and $a 5$ subunits and a $\gamma$ subunit (in addition to the obligatory $\beta$ subunit) (H. Mohler, et al., 2002). Receptors containing the $a 4$ or a 6 subunit do not bind these compounds. Whereas the three $\beta$ subunits $\beta 1-3$ appear to confer identical properties to the receptor complex with respect to modulation by benzodiazepines (as well as by barbiturates and neurosteroids) (Hadingham, et al., 1993), the $\gamma$ subunits contribute somewhat differentially to this process (Benke, et al., 1996). Approximately $85 \%$ of all $\gamma$ subunits are $\gamma 2$ subunits (Benke, et al., 1996), and it has been shown that the $\gamma 2$ subunit is required for behavioral actions of benzodiazepines (Gunther, et al., 1995). Thus, $\mathrm{GABA}_{\mathrm{A}}$ receptors containing a $\gamma 2$ subunit, in combination with $a 1, a 2$, a 3 , or a 5 subunits likely mediate all of the abovementioned behavioral effects of benzodiazepines.

As seen in Fig. 1, approximately $60 \%$ of all $\mathrm{GABA}_{\mathrm{A}}$ receptors contain the a 1 subunit, $15-$ $20 \%$ the a 2 subunit, $10-15 \%$ the a 3 subunit, and 5\% the a 5 subunit $(\mathrm{H}$. Mohler, et al., 2002). In addition to this quantitative difference in their expression levels, the a subunits also show anatomically differential patterns of expression in the CNS. The finding that functionally different neuronal circuits express $\mathrm{GABA}_{\mathrm{A}}$ receptors of specific a subunit compositions preferentially, as well as the differential subcellular, sometimes synapsespecific expression of a subunits within individual neurons, suggested that the a subunits may confer different behavioral functions and thus may constitute targets for specific therapeutic endpoints.

While a few compounds exhibiting relative subtype-selectivity have been developed, no truly subtype-specific compounds have been generated so far. Thus, the traditional pharmacological approach of defining the functions of $\mathrm{GABA}_{\mathrm{A}}$ receptor subtypes by synthesizing novel compounds, while extremely valuable for medication development, was met with limited success for clear assignment of functions to receptor subtypes. This limitation stimulated interest in the development of genetic mouse models that would allow 
unequivocal elucidation of subunit function. To date, several mouse models involving knockouts or point mutations of specific a subunits have been generated and the studies employing these models have provided invaluable information about the functions of different $\mathrm{GABA}_{\mathrm{A}}$ receptor subtypes. For instance, mice carrying histidine to arginine point mutations in one of the four diazepam-sensitive a subunits [a1(H101R), a2(H101R), a 3(H126R) and a 5(H105R)] that transform the diazepam-sensitive a subunits into diazepam-insensitive a subunits have been employed extensively to understand the $\mathrm{GABA}_{\mathrm{A}}$ receptor subtypes that mediate different behavioral actions of benzodiazepines (Rudolph et al., 1999; McKernan, et al., 2000; Low, et al., 2000; Crestani, et al., 2002; Smith et al., 2012). In these mice, the "missing" diazepam actions in mice carrying the mutated a subunit can then be ascribed to the mutant a subunit. The first studies using these point-mutated mice revealed that while wild type mice are sedated by diazepam, a 1(H10R)mice are not sedated by diazepam, but diazepam still has an anxiolytic-like action in these mice (Rudolph, et al., 1999), suggesting that the sedative effects of diazepam are mediated by the a1-containing $\mathrm{GABA}_{\mathrm{A}}$ receptors. Since these early studies, many other studies employing genetic mouse models revealed specific roles for different a subunits, in addition to refining and re-affirming the earlier findings. In a different line of work, human genetics studies revealed associations between different disorders and personality traits and different $a$ subunits. One subunit, the a 2 subunit, has stood out in both lines of research as being linked to many diverse physiological processes and several disorders of the nervous system, suggesting that this subunit might constitute an extremely fruitful drug target. Here, we summarize findings regarding this subunit in relation to different CNS disorders and their treatment.

In each of the sections below, we first summarize findings from human genetics and/or postmortem human studies, followed by findings from animal research, most commonly from gene-targeted mouse models. In many cases the suggestive evidence from human genetics studies can be corroborated by genetically modified mouse models with mechanistic demonstrations of loss or gain of function in animals following genetic manipulations. A review of the two literatures together also provides an easy way to spot gaps in data in either research approach as a guide for future investigations in this area. We start with the well-replicated studies investigating the role of GABRA2 in anxiety, followed by findings relating $G A B R A 2$ to alcohol dependence and drug abuse. Emerging evidence linking $G A B R A 2$ to depression is discussed, followed by a section suggesting the role of $G A B R A 2$ in the brain reward system as the potential common ground for the role of a2containing $\mathrm{GABA}_{\mathrm{A}}$ receptors in substance abuse and depression. We finally discuss the role of $G A B R A 2$ in other CNS disorders, such as schizophrenia and Alzheimer's disease, in the sleep EEG and in pain.

One caveat to note before we begin our discussion is that in many cases other $\mathrm{GABA}_{\mathrm{A}}$ receptor subtypes have also been implicated in a single disorder, as these disorders represent complex neuropathology that involve several brain structures and neurotransmitter systems. The main goal of this review is to demonstrate the potential of a2-containing $\mathrm{GABA}_{\mathrm{A}}$ receptors as valuable drug targets for diverse neuropathology rather than a full discussion of GABAergic mechanisms involved in a certain disorder. While we do discuss other $\mathrm{GABA}_{\mathrm{A}}$ receptor subtypes briefly at most points, there are also instances where we leave out the discussion of other subunits in order focus on a2-containing $\mathrm{GABA}_{\mathrm{A}}$ receptors. More extensive discussion of other $\mathrm{GABA}_{\mathrm{A}}$ receptor subtypes are available in other recent reviews (Rudolph \& Mohler, 2006; Rudolph \& Knoflach; 2011). 


\section{GABRA2 and Anxiety}

The evidence linking the GABA system to anxiety and anxiety disorders is extensive [see (Kalueff \& Nutt, 2007; Mohler, 2012 for reviews]. GABAergic drugs, such as benzodiazepines have been used to treat anxiety disorders for more than half a century. Surprisingly, human genetics studies linking $\mathrm{GABA}_{\mathrm{A}}$ receptor subunits and anxiety phenotypes are limited in number and have revealed relatively weak results. A few studies suggested a possible link between the $G A B R A 2$ gene and anxiety. For instance, Nelson, et al. (2009) reported that polymorphisms in $G A B R A 2$ interact with early childhood trauma in increasing the risk for PTSD, andEnoch et al. (2006) reported anxiety as a mediating factor in the link between alcoholism and $G A B R A 2$ (see below). A study of healthy college students revealed a strong correlation between $G A B R A 2$ genotype and amygdalar and insular activation in response to fearful faces (Stein et al., 2006), a phenotype also observed in patients with anxiety disorders [e.g., (Stein et al., 2002; 2007; Cannistraro, et al., 2004). In contrast to this suggestive evidence, a study investigating $26 \mathrm{SNPs}$ from four $\mathrm{GABA}_{\mathrm{A}}$ receptor genes (GABRA2, GABRA3, GABRA6 and GABRG2) found that the major allelic variation in none of these genes significantly contributed to liability to anxiety disorders (Pham, et al., 2009).

While the findings from human genetics studies do not provide strong and unequivocal evidence for the involvement of GABRA2 in anxiety disorders, studies employing genetargeted mouse models provide strong evidence for the involvement of a2-containing $\mathrm{GABA}_{\mathrm{A}}$ receptors in anxiety, as well as in the anxiolytic effects of benzodiazepines. The first viable $\mathrm{GABA}_{\mathrm{A}}$ receptor knockout mice, the $\gamma 2$ heterozygous knockouts, had a developmental anxiety phenotype that could be reversed with very low doses of benzodiazepines (Crestani, et al., 1999; Gunther, et al., 1995; Earnheart, et al., 2007). However, since the $\gamma 2$ subunit is associated with all six a subunits, the question of which $\mathrm{GABA}_{\mathrm{A}}$ receptor subtype(s), as defined by the a subunits, mediates this anxiety-related profile was left open until the generation of mice carrying histidine-to-arginine point mutations that render the affected subunit insensitive to benzodiazepines. Studies with these mice reported that diazepam has no anxiolytic-like action in a 2(H101R) mice (Low, et al., 2000). In a recent study (Smith, et al., 2012), we replicated and extended these early findings in mice of a C57BL/6J background, showing that the a2-containing $\mathrm{GABA}_{\mathrm{A}}$ receptors were required for the anxiolytic effects of both diazepam and chlordiazepoxide in tests of unconditioned anxiety (i.e., elevated plus maze; Fig. 2E), as well as conditioned fear (i.e., fear-potentiated startle; Fig. 2A-D), controlling for nonspecific variables such as general locomotor activity. Moreover, these observations were independently confirmed by a study showing that diazepam and pentobarbital are no longer anxiolytic in a 2 global knockout mice (Dixon, et al., 2008). Thus, drug-binding to a2-containing $\mathrm{GABA}_{\mathrm{A}}$ receptors is required for the anxiolytic effects of GABAergic drugs.

In a series of drug-free experiments, Vollenweider et al. (2011) showed that heterozygous a 2 knockout mice exhibit heightened anxiety in novelty-suppressed feeding test. Interestingly, in the same study the homozygous a 2 knockout mice did not display this phenotype, and the reasons for this are currently unclear. One potential speculation is that in the homozygous a 2 knockout mice upregulation of the a 3 and a 4 subunits (Panzanelli et al., 2011) might be more pronounced than in the heterozygous a 2 knockout mice and functionally compensate for the loss of the a 2 subunit.

While the involvement of a2-containing $\mathrm{GABA}_{\mathrm{A}}$ receptors in anxiety and anxiolytic drug effects is clear, a few other studies have suggested that the a 3 -containing $\mathrm{GABA}_{\mathrm{A}}$ receptors may also be involved in modulating anxiety (Dias, et al., 2005; Atack, et al., 2006). However, the evidence for this is still not unequivocal [see Smith \& Rudolph, 2012 for a 
discussion]. Similarly, we have recently demonstrated that the a1-containing $\mathrm{GABA}_{\mathrm{A}}$ receptors may be involved in the fear-reducing effects of benzodiazepines in models of conditioned fear, while these receptors are not involved in anxiolysis in models of unconditioned anxiety (Smith, et al., 2012). This finding is exciting in terms of reiterating a long-discussed phenomenon that unconditioned anxiety and conditioned fear have separate neuronal mechanisms and animal models of each behavior tap into different functions. This idea is also reflected in terms of the representation of human disorders at the level of animal models. For example, the elevated plus maze has some face and predictive validity for generalized anxiety disorders, while fear-potentiated startle is frequently considered to be a model of post-traumatic stress disorder. The finding that the two tests might involve partially different $\mathrm{GABA}_{\mathrm{A}}$ receptor subtypes raises the possibility that GABAergic pharmacological interventions for specific anxiety disorders can be differentially tailored. While interesting in providing a functional dissociation that may have clinical implications, these findings also require further replication before any solid conclusions can be drawn.

\subsection{Anxioselective compounds}

Since the introduction of benzodiazepines into clinical practice, it has been a goal to develop a compound with anxiolytic effects comparable to that of diazepam but without sedation. The findings already mentioned above that a 1 -containing $\mathrm{GABA}_{\mathrm{A}}$ receptors mediate the sedative action of diazepam (Rudolph et al., 1999; McKernan et al.,2000), while a2containing $\mathrm{GABA}_{\mathrm{A}}$ receptors mediate the anxiolytic-like action of diazepam (Low, et al., 2000) suggest that a compound which is active at a2-containing $\mathrm{GABA}_{\mathrm{A}}$ receptors but not at a1-containing $\mathrm{GABA}_{\mathrm{A}}$ receptors might be a non-sedative anxiolytic. L-838,417, a benzodiazepine site (BZ site) partial agonist at a2-, a3-, and a5-containing $\mathrm{GABA}_{\mathrm{A}}$ receptors and an antagonist at a 1-containing $\mathrm{GABA}_{\mathrm{A}}$ receptors is indeed anxiolytic-like in the elevated plus maze, but not sedative in rodents (McKernan, et al., 2000). An a2/a 3 BZ site partial agonist, TPA023, also referred to as MK0777, had anxiolytic effects in the elevated plus maze, the fear-potentiated startle paradigm, and in a conditioned suppression of drinking paradigm in rats, as well as reducing conditioned emotional responding in squirrel monkeys (Atack, et al., 2006). It did not have sedative effects in any of the species tested. The a 2/a 3 BZ site partial agonist TPA023 has also been tested in Phase III studies in humans, and some evidence has been presented indicating that in humans this compound is anxiolytic but not sedative (Atack, 2010). Unfortunately, due to preclinical toxicity (cataracts), development of this compound has been stopped (Mohler, 2011).

\section{GABRA2 and Alcohol Dependence}

While it is known that ethanol can potentiate $\mathrm{GABA}_{\mathrm{A}}$ receptors in vitro, the contribution of this potentiation to the effects of ethanol continues to be controversial. Most synaptic $\mathrm{GABA}_{\mathrm{A}}$ receptors show sensitivity to ethanol only at concentrations above the drunk driving limit in many states. One reported exception to this, although not universally accepted (Borghese, et al., 2006) (Yamashita, et al., 2006) are the extrasynaptic $a 4 \beta 3 \delta \mathrm{GABA}_{\mathrm{A}}$ receptors, which are modulated by "social" concentrations of ethanol (Wallner, et al., 2003) and have also been termed the "one glass of wine receptors" (Olsen et al., 2007).

While it is still unknown how ethanol exerts its actions in the CNS, human genetic studies revealed that small nucleotide polymorphisms (SNP) in the GABRA2 gene encoding the $\mathrm{GABA}_{\mathrm{A}}$ receptor a 2 subunit are associated with alcohol dependence (Edenberg, et al., 2004). More specifically, $G A B R A 2$ polymorphisms have been linked to the subjective response to ethanol (Pierucci-Lagha, et al., 2005), where the hedonic value of alcohol changes as a factor of the $G A B R A 2 \times$ breath alcohol concentration interaction (Haughey, et al., 2008). In addition to the subjective response to alcohol, $G A B R A 2$ genotype seems to affect responses to alcohol-related cues. In an fMRI study using a sample of individuals not 
undergoing treatment for substance abuse/dependence, subjects homozygous for the highrisk allele at rs 2798 displayed an increased response to alcohol-associated cues in medial frontal cortical areas compared to heterozygous subjects. In contrast, the heterozygous subjects displayed an increased response in the ventral tegmental area (Kareken, et al., 2010). Finally, in a family sample enriched for alcoholism, GABRA2 polymorphisms were found to be linked to increased activation in the insula with reward anticipation, suggesting that $G A B R A 2$ polymorphisms may be linked to not only alcohol reward and alcohol-related cues, but to a general dysfunction of the reward system in alcohol-dependent subjects (Villafuerte et al., 2012).

It has been reported that a consistent elevation in the risk for alcohol dependence associated with $G A B R A 2$ is not apparent until the mid-20s and then remains constant throughout adulthood (Dick, et al., 2006b; Kramer, et al., 2008). A gene-environment correlation and a gene-environment interaction associated with $G A B R A 2$, marital status and alcohol dependence have been reported, suggesting that $G A B R A 2$ interacts with environmental factors and life style in determining the risk for alcohol dependence (Dick, et al., 2006a). Several studies have also noted $G A B R A 2 \times$ environmental effects×personality traits interactions on alcohol dependence risk. For example, the interaction between parental monitoring as measured at age 11 and $G A B R A 2$ polymorphisms was evaluated in a community-based sample where the output measure was externalizing behaviors (i.e., outward behavior that involves negative interactions with the environment, such as physical aggression, that is seen as a relatively stable personality construct) of the adolescents involved in the study measured longitudinally between 12 to 22 years of age. In this study, two classes of behaviors were distinguished: a stable highly externalizing class, and a moderate externalizing behavior class that showed diminishing externalizing behavior over time. Children exhibiting highly externalizing behavior were more likely to carry the $G A B R A 2$ genotype associated with alcohol dependence, and with high levels of parental monitoring the association of $G A B R A 2$ polymorphism with externalizing behavior diminished (Dick, et al., 2009). GABRA2 polymorphisms have also been linked to impulsiveness, a trait known to be associated with substance abuse, in samples enriched for alcoholism (Villafuerte, et al., 2012). The haplotype conferring high risk for alcohol dependence was also found to be associated with characteristics of alcohol withdrawal and severity of alcohol dependence (delirium tremens, withdrawal seizures) (Soyka, et al., 2008). Finally, GABRA2 may also be involved in therapeutic outcomes for alcoholdependent patients. In a study looking at an association between high-risk and low-risk alleles and responses to three types of psychosocial treatment for alcoholism, it was found that the low-risk allele was associated with greater difference in drinking outcomes between the treatments, compared to the high-risk allele, specifically enhancing the outcomes of twelve-step facilitation (TSF) over Cognitive Behavioral Therapy (CBT) and Motivational Enhancement Therapy (MET) (Bauer, et al., 2007).

The polymorphisms described above do not affect the coding sequence of the GABRA2 gene, and the question arises whether high-risk and low-risk alleles display different levels of gene expression. In postmortem prefrontal cortical tissue, the GABRA2 mRNA levels differed significantly between genotypes (AA, AG, and GG at marker rs279858), being lower in heterozygous AG individuals than in homozygous AA and GG individuals. Interestingly, AA and GG individuals reported greater alcohol-induced positive mood and feelings of vigor after an oral alcohol challenge as compared to AG individuals, suggesting that AA and GG individuals may be more sensitive than AG individuals to the rewarding effects of ethanol, and that this may go along with a higher risk of AA and GG individuals compared to AG individuals for developing alcohol dependence (Haughey, et al., 2008). However, while the reduction of GABRA2 mRNA in the prefrontal cortices of $\mathrm{AG}$ individuals was clearly demonstrated, the $\mathrm{GABA}_{\mathrm{A}}$ receptor a2 subunit protein level was not 
significantly decreased, potentially due to an insufficient number of samples tested (Haughey, et al., 2008).

In summary, $G A B R A 2$ has been linked to the general risk for alcohol dependence and to specific processes involved in alcohol abuse, such as subjective response to alcohol, response to alcohol cues, severity of withdrawal responses, as well as to treatment outcomes. Some studies also suggested interactions between $G A B R A 2$ and other GABA receptor subunit genes with regards to effects on alcohol dependence. For instance, polymorphic markers in the $G A B R G 1$ gene encoding the $\mathrm{GABA}_{\mathrm{A}}$ receptor $\gamma 1$ subunit, which is adjacent to the $G A B R A 2$ gene (intergenic distance $\sim 90 \mathrm{~kb}$ ), have been found to be in linkage disequilibrium with markers on the $G A B R A 2$ gene and to contribute to risk of alcohol dependence in an additive manner, whereas the polymorphic markers in the GABRA2 gene appear to have a dominant effect (Covault et al., 2008). Other researchers reported that the $G A B R A 2$ and $G A B R G 1$ genes likely provide independent contributions to alcohol vulnerability (Enoch, et al., 2009). The function of a2-containing $\mathrm{GABA}_{\mathrm{A}}$ receptors has recently been assessed in a2(S270H/L277A) knock-in mice in which the a2-containing $\mathrm{GABA}_{\mathrm{A}}$ receptors are insensitive to potentiation by ethanol. Most importantly, these mice did not develop the typical conditioned taste aversion to ethanol, and they displayed a complete loss of the motor stimulant effect of ethanol, and decreased ethanol-induced hypnosis. Interestingly, the anxiolytic-like effect of ethanol was still present in these mice (Blednov, et al., 2011). This report suggests that at least certain effects of ethanol, such as the hypnotic and motor-stimulant effect, are dependent on the potentiation of a2-containing $\mathrm{GABA}_{\mathrm{A}}$ receptors. Considering the convincing evidence that the a2-containing $\mathrm{GABA}_{\mathrm{A}}$ receptors are required for benzodiazepine-induced anxiolysis, the finding that ethanolinduced anxiolysis is still present in these animals is surprising. It is possible that the anxiolytic effects of ethanol are mediated by more than one $\mathrm{GABA}_{\mathrm{A}}$ receptor subtype and the potentiation of other subtypes (e.g., a4-containing $\mathrm{GABA}_{\mathrm{A}}$ receptors) is sufficient to generate this effect. These findings start to provide a neurobiological basis for the human genetics studies linking $G A B R A 2$ polymorphisms to altered responses to ethanol in humans, however, further studies are needed to clarify the role of a 2 -containing $\mathrm{GABA}_{\mathrm{A}}$ receptors in processes such as ethanol reward, ethanol-induced anxiolysis and ethanol withdrawal.

\section{GABRA2 and Substance Abuse}

In addition to alcohol dependence, $G A B R A 2$ polymorphisms are also associated with other drug dependence, both in adolescence and adulthood (Enoch, et al., 2010). A study on African-American men with lifetime DSM-IV single and comorbid diagnoses of alcohol, cocaine, and heroin dependence found one unique haplotype predicting heroin addiction, and another one which was more common in controls and appeared to confer resilience to addiction after exposure to severe childhood trauma. An unlinked SNP (rs11503014) was independently associated with heroin addiction, and also interacted with exposure to childhood trauma in predicting cocaine addiction. These findings suggest that GABRA2 might have at least two independent loci associated with drug addiction (Enoch, et al., 2010). In a separate study, in a sample of mostly Caucasian individuals from Brazil, GABRA2 polymorphisms were associated with cocaine addiction (Dixon, et al., 2010).

In addition to cocaine and heroin addiction, $G A B R A 2$ polymorphisms were also associated with marijuana and illicit drug dependence, and in one study, the association with ethanol dependence came only from individuals with comorbid illicit drug dependence (Agrawal, et al., 2006); see also (Matthews et al., 2007). These findings suggest that the GABRA2 gene may be particularly important in cases of polydrug abuse (Drgon, D'Addario, \& Uhl, 2006). 
Finally, there is an association of $G A B R A 2$ polymorphisms (as well as polymorphism in $G A B R A 4$ and $G A B R E$ ) with nicotine dependence (Agrawal, et al., 2008). However, it should be noted that at least one study found that $G A B R A 2$ allelic associations have detectable but only minor effects on alcohol dependence in the general community and no predictive value for nicotine, marijuana and other illicit drug use (Lind, et al., 2008). In summary, there is suggestive evidence from human genetics studies that $G A B R A 2$ may be involved in addiction to heroin, cocaine and nicotine, and in the use of marijuana and illicit drugs. On the other hand, the results of human genetic studies are very sensitive to the characteristics of the samples tested, and as a result, contradictory findings such as the (Lind, et al., 2008) study mentioned above are not uncommon. Thus, the findings from human studies are far from clear and gene-targeted mouse studies to corroborate and clarify these findings are highly needed. Two such studies (Morris, et al., 2008; Dixon, et al., 2010), investigated the role of a 2 -containing $\mathrm{GABA}_{\mathrm{A}}$ receptors in cocaine-induced behavioral changes. While the a 2 knockout mice showed normal behavioral stimulation to acute cocaine and normal conditioned place-preference to cocaine, the ability of cocaine to potentiate responses to conditioned reinforcement and to cause behavioral sensitization following chronic administration was abolished in a 2 knockout mice. Moreover, benzodiazepine-potentiation of behavioral sensitization to cocaine was abolished in a2(H101R) mice, further confirming the role of the a2-containing $\mathrm{GABA}_{\mathrm{A}}$ receptors in behavioral sensitization. These findings suggest that at least some of the effects of cocaine are modulated by a2-containing $\mathrm{GABA}_{\mathrm{A}}$ receptors (presumably in the medium spiny neurons of the nucleus accumbens according to the Dixon et al., 2010 study). Similar studies that investigate the mechanisms of a2-containing $\mathrm{GABA}_{\mathrm{A}}$ receptor involvement in cocaine abuse are needed to clarify the nature of this relationship, and, clearly, an extension of this work to other drugs of abuse is necessary.

\section{GABRA2 and Depression}

The neurotransmitter GABA has been implicated to play a role in depression. For instance, GABA levels are reduced in the brains of patients with major depression (MDD) and are normalized following chronic treatment with antidepressants (Sanacora et al., 2002; 2004). Genetic associations have been reported between MDD and the genes encoding several $\mathrm{GABA}_{\mathrm{A}}$ receptor subtypes, such as $G A B R A 1$ and $G A B R A 5$ (Oruc, et al., 1997; Horiuchi, et al., 2004), but none of these studies have implicated $G A B R A 2$ so far. This is interesting considering the high comorbidity of anxiety disorders and MDD, and the importance of stress as a vulnerability factor for MDD. The central role of $G A B R A 2$ in fear and anxiety processes, as reviewed above, raises the expectation that $G A B R A 2$ would play a role in depressive symptomatology. While human genetics studies have not provided evidence for this, some recent studies using gene-targeted mouse models point to a relationship in this direction.

The initial evidence that reduction of GABAergic function can result in depressive-like behavior came from the heterozygous $\gamma 2$ knockout mice, which, as described above, also exhibit trait anxiety. In tests of behavioral despair, these mice exhibited a developmental depressive-like phenotype that could be rescued by chronic administration of desipramine, but not fluoxetine (Earnheart, et al., 2007; Shen, et al., 2010). Further studies to elucidate the $\mathrm{GABA}_{\mathrm{A}}$ receptor subtypes involved in this effect initially focused on the a 3 subunit. Interestingly, a 3 knockout mice showed reduced depressive-like behavior in tests of behavioral despair, suggesting that the activation of the a 3 -containing $\mathrm{GABA}_{\mathrm{A}}$ receptors would have pro-depressant actions (Fiorelli et al., 2008). In contrast, recent studies with a 2 knockout mice (Vollenweider et al., 2011) showed that the knockout animals have a depressive-like phenotype in tests of behavioral despair (Fig. 3), similar to heterozygous $\gamma 2$ knockout mice. These results suggest that $\mathrm{a} 2$ - and $\mathrm{a} 3$-containing $\mathrm{GABA}_{\mathrm{A}}$ receptors may 
modulate behavioral despair in opposite directions and that the positive modulation of a2containing $\mathrm{GABA}_{\mathrm{A}}$ receptors may have antidepressant effects. However, it should be noted that the tests of behavioral despair such as the forced swim test and the tail suspension test, despite having predictive validity for antidepressant drug action, do not have construct validity for depression per se. Thus, further studies using other paradigms are needed to substantiate the role of a 2 - and a 3 -containing $\mathrm{GABA}_{\mathrm{A}}$ receptors in mood regulation. As noted above, one possible way that the a2-containing receptors may be linked to depressive symptomatology is through their involvement in stress-related responses. Neonatal handling and brief maternal separation have been shown to lead to an increase in the expression of the a 2 subunit in the dentate gyrus of adult animals, and also to increased activity in response to swim stress (Hsu, et al., 2003). These results show that stress during development induces expression changes in the $\mathrm{GABA}_{\mathrm{A}}$ receptor system, which may have functional implications. One interpretation is that the increase in the a 2 subunit is a compensatory mechanism, which is however not sufficient to prevent functional consequences.

The above findings have important potential implications for the development of pharmacological therapies for MDD. While the blockade of serotonin and/or norepinephrine reuptake following the administration of selective serotonin reuptake inhibitors (SSRIs) and tricyclic antidepressants is immediate, the therapeutic antidepressant effects may take up to 6 weeks to develop, suggesting that the antidepressant effects of these drugs probably involve long-term changes in other systems than the serotonergic and noradrenergic systems. Chronic SSRI administration increases brain GABA content in the same time frame that the therapeutic effects start to be observed (Sanacora et al., 2002), suggesting that this adaptation may be at least partially responsible for the antidepressant effects. Indeed, some benzodiazepines, specifically alprazolam and adinazolam, have been demonstrated in clinical studies to elicit antidepressant responses similar to widely prescribed antidepressants in MDD patients, but within the first 2 weeks of treatment (Amsterdam et al., 1986; Petty et al., 1995). The fact that the antidepressant actions of benzodiazepines appear in a much shorter time-frame than those of SSRIs raises the possibility that the SSRI-induced increase in GABA levels in the brain (Sanacora et al., 2002) may be crucial for the antidepressant effects of SSRIs. This view is supported by the experimental observation that heterozygous $\gamma 2$ knockout mice do not display the antidepressant-like actions of SSRIs even after chronic treatment (Shen et al., 2010).

It is not known why some benzodiazepines have antidepressant effects while others don't. Potentially, these benzodiazepines display subtle and as yet unknown differences in relative modulation of $\mathrm{GABA}_{\mathrm{A}}$ receptor subtypes. Based on the preclinical results presented above, it is tempting to speculate that selective agonism at a2-containing $\mathrm{GABA}_{\mathrm{A}}$ receptors might provide a more reliable antidepressant effect than concomitant positive modulation of a 2and a3-containing $\mathrm{GABA}_{\mathrm{A}}$ receptors as is the case with clinically used benzodiazepines.

\section{GABRA2 and Reward}

In the last three sections we have reviewed evidence suggesting a role for a 2-containing $\mathrm{GABA}_{\mathrm{A}}$ receptors in alcohol dependence and other substance abuse, and in depression. One common characteristic of addictive disorders and depression is the dysfunction of the brain reward system. Thus, it is likely that the a 2 -containing $\mathrm{GABA}_{\mathrm{A}}$ receptors play an important role in the functioning of the brain reward system.

Moreover, benzodiazepine abuse and misuse has been long documented among both patients and poly-drug users, suggesting that the positive modulation of the $\mathrm{GABA}_{\mathrm{A}}$ receptors has rewarding effects. The $\mathrm{GABA}_{\mathrm{A}}$ receptor subtypes mediating this effect have only recently started to be studied. 
In a recent series of studies, we first investigated the rewarding actions of benzodiazepines as compared to those of cocaine, and then the $\mathrm{GABA}_{\mathrm{A}}$ receptor subtypes involved in these rewarding actions, using the intracranial self-stimulation (ICSS) paradigm. In this paradigm, animals spin a wheel manipulandum, for which they get rewarded with an electrical stimulation in the medial forebrain bundle at the level of the hypothalamus. In wild type mice, both cocaine and diazepam lead to a left-shift of the dose-reponse curve, i.e. reward enhancement, with comparable effect sizes (Straub, et al., 2010). This is remarkable since benzodiazepines are generally considered to have lower abuse potential than cocaine (see e.g. classification of diazepam as a class 2 drug and of cocaine as a class 4 drug in the US). Moreover, diazepam and cocaine have opposite effects on extracellular dopamine in the nucleus accumbens with cocaine increasing and diazepam decreasing dopamine concentrations (Di Chiara \& Imperato, 1988; Finlay, et al., 1992; Invernizzi, Pozzi, \& Samanin, 1991), indicating that the mechanism of action for the rewarding effects of the two drugs may be different.

Since the a 2 subunit is strongly expressed in the nucleus accumbens, we hypothesized that a2-containing $\mathrm{GABA}_{\mathrm{A}}$ receptors may be mediating the reward-enhancing action of diazepam. Indeed, the above-noted reward-enhancement following diazepam treatment in wild type mice was absent in a2(H101R) mice (Reynolds, et al., 2012; Fig. 4). This indicates that a 2 -containing $\mathrm{GABA}_{\mathrm{A}}$ receptors are necessary for the reward-enhancing action of diazepam. Furthermore, there was an increase in reward thresholds at the highest dose of diazepam in these animals, suggesting that diazepam may even be aversive without the positive modulation of the a2-containing $\mathrm{GABA}_{\mathrm{A}}$ receptors. Our studies similarly demonstrated an abolishment of the reward-enhancing diazepam action in a3(H126R) mice, and a reduction in effect sizes in a $1(\mathrm{H} 101 \mathrm{R})$ mice, suggesting a complex modulation of the reward circuitry by different $\mathrm{GABA}_{\mathrm{A}}$ receptor subtypes, possibly at different points of the system. For example, recent studies have noted the importance of the a1-containing $\mathrm{GABA}_{\mathrm{A}}$ receptors on GABAergic interneurons in the ventral tegmental area in addictivelike properties of benzodiazepines (Tan, et al., 2010), while the above-mentioned Dixon, et al. (2010) study emphasized the importance of a 2 -containing $\mathrm{GABA}_{\mathrm{A}}$ receptors, potentially those expressed in the nucleus accumbens in behavioral sensitization to cocaine. While the study by Tan, et al.(2010) indicates that positive modulation of a 1-containing $\mathrm{GABA}_{\mathrm{A}}$ receptors is required for addictive-like properties of benzodiazepines, so far, there is no experimental evidence on the abuse potential of a highly a2-specific agonist, which, if present, would limit the therapeutic usefulness of such compounds. A more systematic study of the $\mathrm{GABA}_{\mathrm{A}}$ receptors in the brain reward circuitry using gene-targeted models can reveal the exact role of each receptor subtype (i.e., whether they are necessary or sufficient in reward processes) and can provide important insights relevant for the development of novel treatments for psychopathologies such as addiction disorders and MDD.

\section{GABRA2 and Sleep EEG}

Sleep EEG is altered in several psychiatric and neurodegenerative disorders, suggesting that an altered sleep EEG could be an important biomarker for several disorders, as well as a possible factor that exacerbates the neuropathology [see Petit et al., 2004; Steiger \& Kimura, 2010 for reviews). The patients in one of the studies linking polymorphisms in the GABRA2 gene to alcohol dependence had the quantitative endophenotype of increased power in the $\beta$ frequency band (13-28 Hz) of the EEG (Edenberg, et al., 2004), suggesting that changes in sleep EEG may also constitute a part of the neuropathology in alcohol dependence.

Diazepam is known to increase the $\beta$ power in NREM sleep and waking, to decrease $\delta$ activity in NREM sleep and to increase $\theta$ activity during REM sleep. The diazepam-induced increase in $\beta$ power was absent in a2(H101R) mice, indicating that it is mediated by a 2 - 
containing $\mathrm{GABA}_{\mathrm{A}}$ receptors (Kopp et al., 2004). Thus, alcohol dependence is linked to increased power in the $\beta$ frequency band in humans and to the gene encoding the a 2 subunit of the $\mathrm{GABA}_{\mathrm{A}}$ receptor, and in mice positive allosteric modulation of a2-containing $\mathrm{GABA}_{\mathrm{A}}$ receptors results in an increase in $\beta$ power. It is thus tempting to speculate that the $G A B R A 2$ allele(s) associated with alcohol dependence might result in an increased expression of a 2-containing $\mathrm{GABA}_{\mathrm{A}}$ receptors. This would be in line with the finding that the individuals heterozygous (AG) at marker rs 279858 were less sensitive to the rewarding effects of alcohol, were considered to be low risk for alcohol dependence and also had lower GABRA2 mRNA levels compared to the individuals homozygous for either allele in one of the studies reviewed above (Haughey et al., 2008).

In addition, the decrease in $\delta$ activity in NREM sleep and the increase in $\theta$ activity following diazepam treatment in REM sleep were both attenuated in a2(H101R) mice compared to wild type controls, suggesting a role for a2-containing $\mathrm{GABA}_{\mathrm{A}}$ receptors in these effects (Kopp, et al., 2004). Moreover, the involvement of a2-containing $\mathrm{GABA}_{\mathrm{A}}$ receptors in $\theta$ band activity seems to be state-specific, as the diazepam effects on awake $\theta$ activity is unchanged in a2(H101R) mice.

As mentioned previously, a 1-containing $\mathrm{GABA}_{\mathrm{A}}$ receptors have been found to be necessary for the sedative action of diazepam (Rudolph et al., 1999; Rudolph \& Antkowiak, 2004), and they are also likely sufficient, since the potentiation of a1-containing $\mathrm{GABA}_{\mathrm{A}}$ receptors by the a 1-preferring agonist zolpidem is sufficient to produce sedation (Crestani et al., 2000). The initial expectation was therefore that a1-containing $\mathrm{GABA}_{\mathrm{A}}$ receptors would also mediate key effects of diazepam on the sleep EEG. However, diazepam's effects on sleep latency, REM sleep inhibition, and effects on the EEG were all present in the a 1(H101R) mice (Tobler et al., 2001). Interestingly, the decrease in $\delta$ frequencies was even more pronounced in the a $1(\mathrm{H} 101 \mathrm{R})$ mice compared to wild type, as was the number of brief awakenings. From these EEG findings it appears that a1-containing $\mathrm{GABA}_{\mathrm{A}}$ receptors do not necessarily play a major role in the sleep-promoting action of diazepam, and that the a2containing $\mathrm{GABA}_{\mathrm{A}}$ receptors may at least partially mediate this action.

\section{GABRA2 and Schizophrenia}

GABA abnormalities in the cortex of schizophrenic patients has been a consistent finding of postmortem studies (see Stan \& Lewis, 2012 for a review). Human genetics studies have associated several GABA $\mathrm{A}_{\mathrm{A}}$ receptor subunit genes, such as $G A B R A 1, G A B R A 6$ and $G A B R B 2$, with schizophrenia (Petryshen et al., 2005). While no study has linked GABRA2 polymorphisms to schizophrenia so far, there is evidence from postmortem studies of schizophrenia brains, from pharmacological studies and from gene-targeted mouse studies that suggests an important role for the cortical a2-containing $\mathrm{GABA}_{\mathrm{A}}$ receptors in schizophrenia-related cognitive impairments. According to the glutamatergic hypothesis of schizophrenia (see Tsai and Coyle, 2002 for a review), hypofunction of NMDA receptors on parvalbumin-positive GABAergic interneurons in the prefrontal cortex is an essential component of the pathophysiology of schizophrenia (Lisman et al., 2008). Knocking out the NMDA receptor NR1 subunit in GABAergic interneurons in mice has indeed revealed a schizophrenia-like phenotype (Belforte et al., 2010). Postmortem analysis revealed that the glutamate transporter 1 (GAT1) is downregulated and that the $\mathrm{GABA}_{\mathrm{A}}$ receptor a 2 subunit is upregulated in the axon initial segments, the projection zone of a subset of parvalbuminpositive interneurons, in schizophrenic brains (Lewis, et al., 2005). Both observations are consistent with compensatory changes counteracting the decreased activation of the GABAergic parvalbumin-positive interneurons. It has been suggested that the upregulation of the a 2 subunit in the axon initial segment might not be sufficient, and that a positive 
allosteric modulation of a2-containing $\mathrm{GABA}_{\mathrm{A}}$ receptors might have a beneficial effect on the cognitive deficits in schizophrenic patients.

A first clinical study with 15 patients using TPA023 (i.e., MK-0777), an a 2/a 3-selective partial agonist at the benzodiazepine site, showed some improvements in cognitive tests and an increased frontal $\gamma$ power band (Lewis et al., 2008). However, in a second, independent study with 60 patients no cognitive improvements were seen (Buchanan, et al., 2011). It should be noted that the relative efficacy of TPA023 compared to chlordiazepoxide is only $11 \%$ at a2-containing $\mathrm{GABA}_{\mathrm{A}}$ receptors (Atack et al., 2006). Thus, it is possible that the efficacy of TPA023 was too low, and that a compound with higher efficacy at a2-containing $\mathrm{GABA}_{\mathrm{A}}$ receptors might provide unequivocal cognitive improvements. It is noteworthy that TPA023 reversed ketamine-induced impairments in spatial working memory in rhesus monkeys, but not ketamine-induced hallucinatory-like behaviors, which indicates the functional specificity of positive allosteric modulation of a 2- (and possibly a 3-) containing $\mathrm{GABA}_{\mathrm{A}}$ receptors (Castner et al., 2010).

While studied so far only in the context of schizophrenia, these findings may have implications for other disorders that involve cognitive impairments, such as neurodegenerative disorders. Indeed, abnormal GABAergic function and changes in the $\mathrm{GABA}_{\mathrm{A}}$ receptor subunit mRNA levels have been noted in Alzheimer's disease (AD) and Parkinson's disease (Luchetti, et al., 2011), and shifted excitation/inhibition balance has been suggested as a major contributor to cognitive decline in Alzheimer's disease (Rissman $\&$ Mobley, 2011). A recent study found an age-related reduction of GABA currents in AD brains, a faster rate of desensitization, and a reduced sensitivity for GABA. Furthermore, an increase in the transcripts for the a 2 subunit was one of the changes observed AD brains, along with increases or decreases in the transcripts for other subunits (Limon, et al., 2012). Benzodiazepine binding sites have been shown to have a stable decline with aging in the rat brain (Hoekzema, et al., 2012) and there is some evidence that the a 2 mRNA also diminishes in the human prefrontal cortex with age, at least during the time from the neonatal period all the way into adulthood (Fillman et al., 2010). It is possible that digressions from the normal rate of a2-expression decline can underlie cognitive impairments in different aging-related diseases. Finally, a reduction of the a 2 subunit has also been reported in brains from autistic patients (Fatemi et al., 2009), showing a possible linkage of this subunit in cognitive deficits unrelated to aging.

\section{GABRA2 and Pain}

While diazepam is not usually considered to be an analgesic agent, intrathecal administration of diazepam in rodents which does not cause motor sedation has an antihyperalgesic effect, e.g. in paradigms for neuropathic and inflammatory pain, where it increases the paw withdrawal latencies. Studies with mice carrying point-mutated diazepaminsensitive a subunits indicated that diazepam-induced analgesia is mediated by a2- and a3- containing $\mathrm{GABA}_{\mathrm{A}}$ receptors in an animal model of inflammatory pain and by a 2-, a3-, and a5-containing $\mathrm{GABA}_{\mathrm{A}}$ receptors in an animal model of neuropathic pain and in a model of tonic nociception. In these models, the contributions of a 2 -containing $\mathrm{GABA}_{\mathrm{A}}$ receptors appear to be strongest (Knabl, et al., 2008; 2009). In line with this finding, diazepaminduced potentiation of GABAergic membrane currents in dorsal root ganglion neurons were reduced in a $2(\mathrm{H} 101 \mathrm{R})$ mice, while the same parameter was attenuated in intrinsic dorsal horn neurons in both a2(H101R) mice and in a3(H126R) mice (Knabl, et al., 2008). L-838,417, a BZ site partial antagonist at a2-, a3-, and a5- containing $\mathrm{GABA}_{\mathrm{A}}$ receptors but an antagonist at a1-containing $\mathrm{GABA}_{\mathrm{A}}$ receptors induces analgesia in rats, and there is no tolerance to this analgesic action during a 10 day period (Knabl, et al., 2008). fMRI studies revealed that L-838,417 also reduced the activity of brain areas related to the 
associate-emotional components of pain (Knabl, et al., 2008). Other partial allosteric modulators of a 2-, a3-, and/or a 5-containing $\mathrm{GABA}_{\mathrm{A}}$ receptors, including TPA023 and NS11934 have also been shown to have analgesic actions in models of inflammatory and neuropathic pain; interestingly, diazepam was ineffective in these models for reasons which are not understood, demonstrating that subtype-selective compounds can have actions different from those of classical benzodiazepines (Munro, et al., 2008; 2011).

\section{Conclusion}

While the role of a2-containing $\mathrm{GABA}_{\mathrm{A}}$ receptors in benzodiazepine-induced anxiolysis has been known for a long time (Low et al., 2000), more recent studies reveal the involvement of these receptors in processes as diverse as reward and alcohol/drug abuse, schizophrenic symptomatology, depression and chronic pain. Since a2-containing $\mathrm{GABA}_{\mathrm{A}}$ receptors do not mediate sedation (Rudolph, et al., 1999) (McKernan, et al., 2000), it is predicted that a 2 -specific agonists would not be compounded by sedation. a 2 -specific agonists would be predicted to be therapeutically useful for anxiety disorders and possibly depression, with the involvement of the a2-subunit in reward processes suggesting that the positive modulation of these receptors may help with the anhedonic responses in major depression. The recent finding that positive modulation of a 1-containing $\mathrm{GABA}_{\mathrm{A}}$ receptors is required for the addictive properties of benzodiazpines (Tan, et al., 2010) suggests that a2-specific agonists may lack significant abuse potential, although this still has to be demonstrated experimentally. The use of a2-specific agonists in the treatment of chronic pain would also address the increased anxiety that is frequently comorbid with chronic pain. It is our belief that the potential for $\mathrm{GABA}_{\mathrm{A}}$-receptor subtype specific compounds will become more evident as further studies clarify the role of $a 2$ and other $\mathrm{GABA}_{\mathrm{A}}$ receptor subtypes in different processes.

\section{Acknowledgments}

Research by the authors on $\mathrm{GABA}_{\mathrm{A}}$ receptors was or is supported by grants from the National Institutes of Health to UR (award numbers GM086448, MH080006, MH085149, DA027571, DA026578, MH094834 and MH095905). The content is solely the responsibility of the authors and does not necessarily represent the official views of the National Institute of General Medical Sciences, the National Institute of Mental Health and the National Institute on Drug Abuse, or the National Institutes of Health. EE was supported by the Eleanor and Miles Shore Harvard Medical School Fellowship.

\section{Abbreviations}

GABRA2 $\gamma$-aminobutyric acid (GABA) A receptor, $a 2$

CNS central nervous system

\section{References}

Agrawal A, Edenberg HJ, Foroud T, Bierut LJ, Dunne G, Hinrichs AL, Nurnberger JI, Crowe R, Kuperman S, Schuckit MA, Begleiter H, Porjesz B, Dick DM. Association of GABRA2 with drug dependence in the collaborative study of the genetics of alcoholism sample. Behavior Genetics. 2006; 36:640-650. [PubMed: 16622805]

Agrawal A, Pergadia ML, Saccone SF, Hinrichs AL, Lessov-Schlaggar CN, Saccone NL, Neuman RJ, Breslau N, Johnson E, Hatsukami D, Montgomery GW, Heath AC, Martin NG, Goate AM, Rice JP, Bierut LJ, Madden PA. Gamma-aminobutyric acid receptor genes and nicotine dependence: evidence for association from a case-control study. Addiction. 2008; 103:1027-1038. [PubMed: 18482426] 
Amsterdam JD, Kaplan M, Potter L, Bloom L, Rickels K. Adinazolam, a new triazolobenzodiazepine, and imipramine in the treatment of major depressive disorder. Psychopharmacology. 1986; 88:484488. [PubMed: 3085137]

Atack JR. GABA A receptor alpha2/alpha3 subtype-selective modulators as potential nonsedating anxiolytics. Current Topics in Behavioral Neurosciences. 2010; 2:331-360. [PubMed: 21309116]

Atack JR, Wafford KA, Tye SJ, Cook SM, Sohal B, Pike A, Sur C, Melillo D, Bristow L, Bromidge F, Ragan I, Kerby J, Street L, Carling R, Castro JL, Whiting P, Dawson GR, McKernan RM. TPA023 [7-(1,1-dimethylethyl)-6-(2-ethyl-2H-1,2,4-triazol-3-ylmethoxy)- 3-(2-fluorophenyl)-1,2,4triazolo[4,3-b]pyridazine], an agonist selective for alpha2- and alpha3- containing $\mathrm{GABA}_{\mathrm{A}}$ receptors, is a nonsedating anxiolytic in rodents and primates. Journal of Pharmacology \& Experimental Therapeutics. 2006; 316:410-422. [PubMed: 16183706]

Bauer LO, Covault J, Harel O, Das S, Gelernter J, Anton R, Kranzler HR. Variation in GABRA2 predicts drinking behavior in project MATCH subjects. Alcoholism: Clinical \& Experimental Research. 2007; 31:1780-1787.

Belforte JE, Zsiros V, Sklar ER, Jiang Z, Yu G, Li Y, Quinlan EM, Nakazawa K. Postnatal NMDA receptor ablation in corticolimbic interneurons confers schizophrenia-like phenotypes. Nat Neurosci. 2010; 13:76-83. [PubMed: 19915563]

Benke D, Honer M, Michel C, Mohler H. GABA $\mathrm{A}$ receptor subtypes differentiated by their gammasubunit variants: prevalence, pharmacology and subunit architecture. Neuropharmacology. 1996; 35:1413-1423. [PubMed: 9014158]

Blednov YA, Borghese CM, McCracken ML, Benavidez JM, Geil CR, Osterndorff-Kahanek E, Werner DF, Iyer S, Swihart A, Harrison NL, Homanics GE, Harris RA. Loss of ethanol conditioned taste aversion and motor stimulation in knockin mice with ethanolinsensitive alpha2-containing GABA(A) receptors. Journal of Pharmacology \& Experimental Therapeutics. 2011; 336:145-154. [PubMed: 20876231]

Borghese CM, Storustovu S, Ebert B, Herd MB, Belelli D, Lambert JJ, Marshall G, Wafford KA, Harris RA. The delta subunit of gamma-aminobutyric acid type A receptors does not confer sensitivity to low concentrations of ethanol. Journal of Pharmacology \& Experimental Therapeutics. 2006; 316:1360-1368. [PubMed: 16272217]

Buchanan RW, Keefe RS, Lieberman JA, Barch DM, Csernansky JG, Goff DC, Gold JM, Green MF, Jarskog LF, Javitt DC, Kimhy D, Kraus MS, McEvoy JP, Mesholam-Gately RI, Seidman LJ, Ball MP, McMahon RP, Kern RS, Robinson J, Marder SR. A randomized clinical trial of MK-0777 for the treatment of cognitive impairments in people with schizophrenia. Biological Psychiatry. 2011; 69:442-449. [PubMed: 21145041]

Cannistraro PA, Wright CI, Wedig MM, Martis B, Shin LM, Wilhelm S, Rauch SL. Amygdala responses to human faces in obsessive-compulsive disorder. Biological Psychiatry. 2004; 56:916920. [PubMed: 15601600]

Castner SA, Arriza JL, Roberts JC, Mrzljak L, Christian EP, Williams GV. Reversal of ketamineinduced working memory impairments by the GABA $A_{A}$ alpha2/3 agonist TPA023. Biological Psychiatry. 2010; 67:998-1001. [PubMed: 20189164]

Covault J, Gelernter J, Jensen K, Anton R, Kranzler HR. Markers in the 5'-region of GABRG1 associate to alcohol dependence and are in linkage disequilibrium with markers in the adjacent GABRA2 gene. Neuropsychopharmacology. 2008; 33:837-848. [PubMed: 17507911]

Crestani F, Keist R, Fritschy JM, Benke D, Vogt K, Prut L, Bluthmann H, Mohler H, Rudolph U. Trace fear conditioning involves hippocampal $5 \mathrm{GABA}_{\mathrm{A}}$ receptors. Proc Natl Acad Sci U S A. 2002; 99:8980-8985. [PubMed: 12084936]

Crestani F, Lorez M, Baer K, Essrich C, Benke D, Laurent JP, Belzung C, Fritschy JM, Luscher B, Mohler H. Decreased $\mathrm{GABA}_{\mathrm{A}}$-receptor clustering results in enhanced anxiety and a bias for threat cues. Nat Neurosci. 1999; 2:833-839. [PubMed: 10461223]

Crestani F, Martin JR, Mohler H, Rudolph U. Mechanism of action of the hypnotic zolpidem in vivo. British Journal of Pharmacology. 2000; 131:1251-1254. [PubMed: 11090095]

Di Chiara G, Imperato A. Drugs abused by humans preferentially increase synaptic dopamine concentrations in the mesolimbic system of freely moving rats. Proceedings of the National Academy of Sciences of the United States of America. 1988; 85:5274-5278. [PubMed: 2899326] 
Dias R, Sheppard WF, Fradley RL, Garrett EM, Stanley JL, Tye SJ, Goodacre S, Lincoln RJ, Cook SM, Conley R, Hallett D, Humphries AC, Thompson SA, Wafford KA, Street LJ, Castro JL, Whiting PJ, Rosahl TW, Atack JR, McKernan RM, Dawson GR, Reynolds DS. Evidence for a significant role of alpha 3-containing $\mathrm{GABA}_{\mathrm{A}}$ receptors in mediating the anxiolytic effects of benzodiazepines. Journal of Neuroscience. 2005; 25:10682-10688. [PubMed: 16291941]

Dick DM, Agrawal A, Schuckit MA, Bierut L, Hinrichs A, Fox L, Mullaney J, Cloninger CR, Hesselbrock V, Nurnberger JI Jr, Almasy L, Foroud T, Porjesz B, Edenberg H, Begleiter H. Marital status, alcohol dependence, and GABRA2: evidence for geneenvironment correlation and interaction. Journal of Studies on Alcohol. 2006a; 67:185-194. [PubMed: 16562401]

Dick DM, Bierut L, Hinrichs A, Fox L, Bucholz KK, Kramer J, Kuperman S, Hesselbrock V, Schuckit M, Almasy L, Tischfield J, Porjesz B, Begleiter H, Nurnberger J Jr, Xuei X, Edenberg HJ, Foroud T. The role of GABRA2 in risk for conduct disorder and alcohol and drug dependence across developmental stages. Behavior Genetics. 2006b; 36:577-590. [PubMed: 16557364]

Dick DM, Latendresse SJ, Lansford JE, Budde JP, Goate A, Dodge KA, Pettit GS, Bates JE. Role of GABRA2 in Trajectories of Externalizing Behavior Across Development and Evidence of Moderation by Parental Monitoring. Archives of General Psychiatry. 2009; 66:649-657. [PubMed: 19487630]

Dixon CI, Morris HV, Breen G, Desrivieres S, Jugurnauth S, Steiner RC, Vallada H, Guindalini C, Laranjeira R, Messas G, Rosahl TW, Atack JR, Peden DR, Belelli D, Lambert JJ, King SL, Schumann G, Stephens DN. Cocaine effects on mouse incentive-learning and human addiction are linked to alpha2 subunit-containing $\mathrm{GABA}_{\mathrm{A}}$ receptors. Proceedings of the National Academy of Sciences of the United States of America. 2010; 107:2289-2294. [PubMed: 20133874]

Dixon CI, Rosahl TW, Stephens DN. Targeted deletion of the GABRA2 gene encoding alpha2subunits of $\mathrm{GABA}(\mathrm{A})$ receptors facilitates performance of a conditioned emotional response, and abolishes anxiolytic effects of benzodiazepines and barbiturates. Pharmacology, Biochemistry \& Behavior. 2008; 90:1-8.

Drgon T, D'Addario C, Uhl GR. Linkage disequilibrium, haplotype and association studies of a chromosome 4 GABA receptor gene cluster: candidate gene variants for addictions. American Journal of Medical Genetics Part. B,. Neuropsychiatric Genetics: the Official Publication of the International Society of Psychiatric Genetics. 2006; 141B:854-860.

Earnheart JC, Schweizer C, Crestani F, Iwasato T, Itohara S, Mohler H, Luscher B. GABAergic control of adult hippocampal neurogenesis in relation to behavior indicative of trait anxiety and depression states. Journal of Neuroscience. 2007; 27:3845-3854. [PubMed: 17409249]

Edenberg HJ, Dick DM, Xuei X, Tian H, Almasy L, Bauer LO, Crowe RR, Goate A, Hesselbrock V, Jones K, Kwon J, Li TK, Nurnberger JI Jr, O'Connor SJ, Reich T, Rice J, Schuckit MA, Porjesz B, Foroud T, Begleiter H. Variations in GABRA2, encoding the alpha 2 subunit of the GABA(A) receptor, are associated with alcohol dependence and with brain oscillations. American Journal of Human Genetics. 2004; 74:705-714. [PubMed: 15024690]

Enoch MA, Hodgkinson CA, Yuan Q, Albaugh B, Virkkunen M, Goldman D. GABRG1 and GABRA2 as independent predictors for alcoholism in two populations. Neuropsychopharmacology. 2009; 34:1245-1254. [PubMed: 18818659]

Enoch MA, Hodgkinson CA, Yuan Q, Shen PH, Goldman D, Roy A. The influence of GABRA2, childhood trauma, and their interaction on alcohol, heroin, and cocaine dependence. Biological Psychiatry. 2010; 67:20-27. [PubMed: 19833324]

Enoch MA, Schwartz L, Albaugh B, Virkkunen M, Goldman D. Dimensional anxiety mediates linkage of GABRA2 haplotypes with alcoholism. American Journal of Medical Genetics. Part. B, Neuropsychiatric Genetics: the Official Publication of the International Society of Psychiatric Genetics. 2006; 141B:599-607.

Fatemi SH, Reutiman TJ, Folsom TD, Thuras PD. GABA(A) receptor downregulation in brains of subjects with autism. Journal of Autism \& Developmental Disorders. 2009; 39:223-230. [PubMed: 18821008]

Fillman SG, Duncan CE, Webster MJ, Elashoff M, Weickert CS. Developmental coregulation of the beta and gamma $\mathrm{GABA}_{\mathrm{A}}$ receptor subunits with distinct alpha subunits in the human dorsolateral prefrontal cortex. International Journal of Developmental Neuroscience. 2010; 28:513-519. [PubMed: 20609421] 
Finlay JM, Damsma G, Fibiger HC. Benzodiazepine-induced decreases in extracellular concentrations of dopamine in the nucleus accumbens after acute and repeated administration. Psychopharmacology. 1992; 106:202-208. [PubMed: 1549647]

Fiorelli R, Rudolph U, Straub CJ, Feldon J, Yee BK. Affective and cognitive effects of global deletion of alpha3-containing gamma-aminobutyric acid-A receptors. Behavioural Pharmacology. 2008; 19:582-596. [PubMed: 18690113]

Gunther U, Benson J, Benke D, Fritschy JM, Reyes G, Knoflach F, Crestani F, Aguzzi A, Arigoni M, Lang Y. Benzodiazepine-insensitive mice generated by targeted disruption of the gamma 2 subunit gene of gamma-aminobutyric acid type A receptors. Proceedings of the National Academy of Sciences of the United States of America. 1995; 92:7749-7753. [PubMed: 7644489]

Hadingham KL, Wingrove PB, Wafford KA, Bain C, Kemp JAPKJ, Wilson AW, Wilcox AS, Sikela JM, Ragan CI, Whiting PJ. Role of the beta subunit in determining the pharmacology of human gamma-aminobutyric acid type A receptors. Molecular Pharmacology. 1993; 44:1211-1218. [PubMed: 8264558]

Haughey HM, Ray LA, Finan P, Villanueva R, Niculescu M, Hutchison KE. Human gammaaminobutyric acid A receptor alpha2 gene moderates the acute effects of alcohol and brain mRNA expression. Genes, Brain, \& Behavior. 2008; 7:447-454.

Hoekzema E, Rojas S, Herance R, Pareto D, Abad S, Jinmenez X, Figueras FP, Popota F, Ruiz A, Flotats N, Fernandez FJ, Rocha M, Rovira M, Victor VM, Gispert JD. In vivo molecular imaging of the GABA/benzodiazepine receptor complex in the aged rat brain. Neurobiology of Aging. 2012; 33:1457-1465. [PubMed: 21272959]

Horiuchi Y, Nakayama J, Ishiguro H, Ohtsuki T, Detera-Wadleigh SD, Toyota T, Yamada K, Nankai M, Shibuya H, Yoshikawa T, Arinami T. Possible association between a haplotype of the GABAA receptor alpha 1 subunit gene (GABRA1) and mood disorders. Biological Psychiatry. 2004; 55:40-45. [PubMed: 14706423]

Hsu FC, Zhang GJ, Raol YS, Valentino RJ, Coulter DA, Brooks-Kayal AR. Repeated neonatal handling with maternal separation permanently alters hippocampal $\mathrm{GABA}_{\mathrm{A}}$ receptors and behavioral stress responses. Proceedings of the National Academy of Sciences of the United States of America. 2003; 100:12213-12218. [PubMed: 14530409]

Invernizzi R, Pozzi L, Samanin R. Release of dopamine is reduced by diazepam more in the nucleus accumbens than in the caudate nucleus of conscious rats. Neuropharmacology. 1991; 30:575-578. [PubMed: 1922681]

Kalueff AV, Nutt DJ. Role of GABA in anxiety and depression. Depression \& Anxiety. 2007; 24:495517. [PubMed: 17117412]

Kareken DA, Liang T, Wetherill L, Dzemidzic M, Bragulat V, Cox C, Talavage T, O'Connor SJ, Foroud TA. polymorphism in GABRA2 is associated with the medial frontal response to alcohol cues in an fMRI study. Alcoholism: Clinical \& Experimental Research. 34:2169-2178.

Klausberger T, Somogyi P. Neuronal diversity and temporal dynamics: the unity of hippocampal circuit operations. Science. 2008; 321:53-57. [PubMed: 18599766]

Knabl J, Witschi R, Hosl K, Reinold H, Zeilhofer UB, Ahmadi S, Brockhaus J, Sergejeva M, Hess A, Brune K, Fritschy JM, Rudolph U, Mohler H, Zeilhofer HU. Reversal of pathological pain through

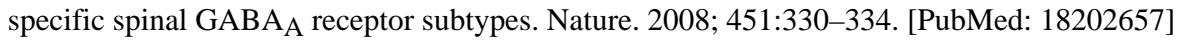

Knabl J, Zeilhofer UB, Crestani F, Rudolph U, Zeilhofer HU. Genuine antihyperalgesia by systemic diazepam revealed by experiments in $\mathrm{GABA}_{\mathrm{A}}$ receptor point-mutated mice. Pain. 2009; 141:233238. [PubMed: 19091469]

Kopp C, Rudolph U, Low K, Tobler I. Modulation of rhythmic brain activity by diazepam: GABA(A) receptor subtype and state specificity. Proceedings of the National Academy of Sciences of the United States of America. 2004; 101:3674-3679. [PubMed: 14990800]

Kramer JR, Chan G, Dick DM, Kuperman S, Bucholz KK, Edenberg HJ, Polgreen LA, Hesselbrock VM, Schuckit MA, Nurnberger JI, Kapp ES, Porjesz B, Bierut LJ. Multiple-domain predictors of problematic alcohol use in young adulthood. Journal of Studies on Alcohol \& Drugs. 2008; 69:649-659. [PubMed: 18781239] 
Lewis DA, Cho RY, Carter CS, Eklund K, Forster S, Kelly MA, Montrose D. Subunitselective modulation of GABA type A receptor neurotransmission and cognition in schizophrenia. Am J Psychiatry. 2008; 165:1585-1593. [PubMed: 18923067]

Lewis DA, Hashimoto T, Volk DW. Cortical inhibitory neurons and schizophrenia. Nature Reviews Neuroscience. 2005; 6:312-324.

Limon A, Reyes-Ruiz JM, Miledi R. Loss of functional GABA(A) receptors in the Alzheimer diseased brain. Proceedings of the National Academy of Sciences of the United States of America. 2012; 109:10071-10076. [PubMed: 22691495]

Lind PA, Macgregor S, Agrawal A, Montgomery GW, Heath AC, Martin NG, Whitfield JB. The role of GABRA2 in alcohol dependence, smoking, and illicit drug use in an Australian population sample. Alcoholism: Clinical \& Experimental Research. 2008; 32:1721-1731.

Lisman JE, Coyle JT, Green RW, Javitt DC, Benes FM, Heckers S, Grace AA. Circuit-based framework for understanding neurotransmitter and risk gene interactions in schizophrenia. Trends in Neurosciences. 2008; 31:234-242. [PubMed: 18395805]

Low K, Crestani F, Keist R, Benke D, Brunig I, Benson JA, Fritschy JM, Rulicke T, Bluethmann H, Mohler H, Rudolph U. Molecular and neuronal substrate for the selective attenuation of anxiety. Science. 2000; 290:131-134. [PubMed: 11021797]

Luchetti S, Huitinga I, Swaab DF. Neurosteroid and GABA-A receptor alterations in Alzheimer's disease, Parkinson's disease and multiple sclerosis. Neuroscience. 2011; 191:6-21. [PubMed: 21514366]

Matthews AG, Hoffman EK, Zezza N, Stiffler S, Hill SY. The role of the GABRA2 polymorphism in multiplex alcohol dependence families with minimal comorbidity: within-family association and linkage analyses. Journal of Studies on Alcohol \& Drugs. 2007; 68:625-633. [PubMed: 17690794]

McKernan RM, Rosahl TW, Reynolds DS, Sur C, Wafford KA, Atack JR, Farrar S, Myers J, Cook G, Ferris P, Garrett L, Bristow L, Marshall G, Macaulay A, Brown N, Howell O, Moore KW, Carling RW, Street LJ, Castro JL, Ragan CI, Dawson GR, Whiting PJ. Sedative but not anxiolytic properties of benzodiazepines are mediated by the $\mathrm{GABA}_{\mathrm{A}}$ receptor 1 subtype. Nat Neurosci. 2000; 3:587-592. [PubMed: 10816315]

Mohler H. The rise of a new GABA pharmacology. Neuropharmacology. 2011; 60:1042-1049. [PubMed: 21035473]

Mohler H. The GABA system in anxiety and depression and its theapeutic potential. Neuropharmacology. 2012; 62:42-53. [PubMed: 21889518]

Mohler H, Fritschy JM, Rudolph U. A new benzodiazepine pharmacology. Journal of Pharmacology \& Experimental Therapeutics. 2002; 300:2-8. [PubMed: 11752090]

Morris HV, Dawson GR, Reynolds DS, Atack JR, Rosahl TW, Stephens DN. Alpha2- containing $\mathrm{GABA}(\mathrm{A})$ receptors are involved in mediating stimulant effects of cocaine. Pharmacology, Biochemistry \& Behavior. 2008; 90:9-18.

Munro G, Erichsen HE, Rae MG, Mirza NR. A question of balance - Positive versus negative allosteric modulation of $\mathrm{GABA}_{\mathrm{A}}$ recetpor subtypes as a driver of analgesic efficacy in rat models of inflammatory and neuropathic pain. Neuropharmacol. 2011; 61:121-132.

Munro G, Lopez-Garcia JA, Rivera-Arconada I, Erichsen HK, Nielsen EO, Larsen JS, Ahring PK, Mirza NR. Comparison of the novel subtype-selective $\mathrm{GABA}_{\mathrm{A}}$ receptor-positive allosteric modulator NS11394 [3'-[5-(1-hydroxy-1-methyl-ethyl)-benzoimidazol-1-yl]-biphenyl-2carbonitrile] with diazepam, zolpidem, bretazenil, and gaboxadol in rat models of inflammatory and neuropathic pain. J Pharmacol Exp Ther. 2008; 327:969-981. [PubMed: 18791060]

Nelson EC, Agrawal A, Pergadia ML, Lynskey MT, Todorov AA, Wang JC, Todd RD, Martin NG, Heath AC, Goate AM, Montgomery GW, Madden PA. Association of childhood trauma exposure and GABRA2 polymorphisms with risk of posttraumatic stress disorder in adults. Molecular Psychiatry. 2009; 14:234-235. [PubMed: 19229201]

Olsen RW, Hanchar HJ, Meera P, Wallner M. GABA A receptor subtypes: the "one glass of wine" receptors. Alcohol. 2007; 41:201-209. [PubMed: 17591543]

Olsen RW, Sieghart W. International Union of Pharmacology. LXX. Subtypes of gammaaminobutyric acid(A) receptors: classification on the basis of subunit composition, pharmacology, and function. Update. Pharmacological Reviews. 2008; 60:243-260. [PubMed: 18790874] 
Oruc L, Verheyen GR, Furac I, Ivezic S, Jakovljevic M, Raeymaekers P, Van Broeckhoven C. Positive association between the GABRA5 gene and unipolar recurrent major depression.

Neuropsychobiology. 1997; 36:62-64. [PubMed: 9267853]

Panzanelli P, Gunn BG, Schlatter MC, Benke D, Tyagarajan SK, Scheiffele P, Belelli D, Lambert JJ, Rudolph U, Fritschy JM. Distinct mechanisms regulate $\mathrm{GABA}_{\mathrm{A}}$ receptor and gephyrin clustering at perisomatic and axo-axonic synapses on CA1 pyramidal cells. Journal of Physiology. 2011; 589:4959-4980. [PubMed: 21825022]

Petit D, Gagnon JF, Fantini ML, Ferini-Strambi L, Montplaisir J. Sleep and quantitative EEG in neurodegenerative disorders. Journal of Psychosomatic Research. 2004; 56:487-496. [PubMed: 15172204]

Petryshen TL, Middleton FA, Tahl AR, Rockwell GN, Purcell S, Aldinger KA, Kirby A, Morley CP, McGann L, Gentile KL, Waggoner SG, Medeiros HM, Carvalho C, Macedo A, Albus M, Maier W, Trixler M, Eichhammer P, Schwab SG, Wildenauer DB, Azevedo MH, Pato MT, Pato CN, Daly MJ, Sklar P. Genetic investigation of chromosome $5 \mathrm{q} \mathrm{GABA}_{\mathrm{A}}$ receptor subunit genes in schizophrenia. Molecular Psychiatry. 2005; 10:1074-1088. [PubMed: 16172613]

Petty F, Trivedi MH, Fulton M, Rush AJ. Benzodiazepines as antidepressants: does GABA play a role in depression? Biological Psychiatry. 1995; 38:578-591. [PubMed: 8573660]

Pham X, Sun C, Chen X, van den Oord EJ, Neale MC, Kendler KS, Hettema JM. Association study between GABA receptor genes and anxiety spectrum disorders. Depression \& Anxiety. 2009; 26:998-1003. [PubMed: 19842164]

Pierucci-Lagha A, Covault J, Feinn R, Nellissery M, Hernandez-Avila C, Oncken C, Morrow AL, Kranzler HR. GABRA2 alleles moderate the subjective effects of alcohol, which are attenuated by finasteride. Neuropsychopharmacology. 2005; 30:1193-1203. [PubMed: 15702134]

Reynolds LM, Engin E, Tantillo G, Lau HM, Muschamp JW, Carlezon WA Jr, Rudolph U. Differential roles of GABA(A) receptor subtypes in benzodiazepine-induced enhancement of brain stimulation reward. Neuropsychopharmacology. 2012 [Epub ahead of print].

Rissman RA, Mobley WC. Implications for treatment: GABA $_{\mathrm{A}}$ receptors in aging, Down syndrome and Alzheimer's disease. Journal of Neurochemistry. 117:613-622. [PubMed: 21388375]

Rudolph U, Antkowiak B. Molecular and neuronal substrates for general anaesthetics. Nature Reviews Neuroscience. 2004; 5:709-720.

Rudolph U, Crestani F, Benke D, Brunig I, Benson JA, Fritschy JM, Martin JR, Bluethmann H, Mohler H. Benzodiazepine actions mediated by specific -aminobutyric acidA receptor subtypes. Nature. 1999; 401:796-800. [PubMed: 10548105]

Rudolph U, Knoflach F. Beyond classical benzodiazepines: novel therapeutic potential of GABAA receptor subtypes. Nature Reviews. Drug Discovery. 2011; 10:685-697.

Rudolph U, Mohler H. GABA-based therapeutic approaches: $\mathrm{GABA}_{\mathrm{A}}$ receptor subtype functions. Current Opinion in Pharmacology. 2006; 6:18-23. [PubMed: 16376150]

Sanacora G, Gueorguieva R, Epperson CN, Wu YT, Appel M, Rothman DL, Krystal JH, Mason GF. Subtype-specific alterations of gamma-aminobutyric acid and glutamate in patients with major depression. Archives of General Psychiatry. 2004; 61:705-713. [PubMed: 15237082]

Sanacora G, Mason GF, Rothman DL, Krystal JH. Increased occipital cortex GABA concentrations in depressed patients after therapy with selective serotonin reuptake inhibitors. American Journal of Psychiatry. 2002; 159:663-665. [PubMed: 11925309]

Shen Q, Lal R, Luellen BA, Earnheart JC, Andrews AM, Luscher B. gamma- Aminobutyric acid-type A receptor deficits cause hypothalamic-pituitary-adrenal axis hyperactivity and antidepressant drug sensitivity reminiscent of melancholic forms of depression. Biological Psychiatry. 2010; 68:512-520. [PubMed: 20579975]

Sigel E, Luscher BP. A closer look at the high affinity benzodiazepine binding site on GABA receptors. Current Topics in Medicinal Chemistry. 2011; 11:241-246. [PubMed: 21189125]

Smith KS, Engin E, Meloni EG, Rudolph U. Benzodiazepine-induced anxiolysis and reduction of conditioned fear are mediated by distinct $\mathrm{GABA}(\mathrm{A})$ receptor subtypes in mice. Neuropharmacology. 2012 Epub 2012 Mar 21.

Smith KS, Rudolph U. Anxiety and depression: mouse genetics and pharmacological approachse to the role of GABA(A) receptor subtypes. Neuropharmacology. 2012; 62:54-62. [PubMed: 21810433] 
Soyka M, Preuss UW, Hesselbrock V, Zill P, Koller G, Bondy B. GABA-A2 receptor subunit gene (GABRA2) polymorphisms and risk for alcohol dependence. Journal of Psychiatric Research. 2008; 42:184-191. [PubMed: 17207817]

Stan A, Lewis DA. Altered cortical GABA neurotransmission in schizophrenia: insights into novel theapeutic strategies. Current Pharmaceutical Biotechnology. 2012 epub ahead of print.

Steiger A, Kimura M. Wake and sleep EEG provide biomarkers in depression. Journal of Psychiatric Research. 44:242-252. [PubMed: 19762038]

Stein MB, Goldin PR, Sareen J, Zorrilla LT, Brown GG. Increased amygdala activation to angry and contemptuous faces in generalized social phobia. Archives of General Psychiatry. 2002; 59:10271034. [PubMed: 12418936]

Stein MB, Paulus MP, Gelernter J. GABRA2 genetic variation and the response of the human amygdala and insula to fearful faces. Biological Psychiatry. 2006; 59:179S-179S.

Stein MB, Simmons AN, Fenstein JS, Paulus MP. Increased amygdala and insula activation during emotion processing in anxiety-prone subjects. American Journal of Psychiatry. 2007; 164:318327. [PubMed: 17267796]

Straub CJ, Carlezon WA Jr, Rudolph U. Diazepam and cocaine potentiate brain stimulation reward in C57BL/6J mice. Behavioural Brain Research. 206:17-20. [PubMed: 19716385]

Tan KR, Brown M, Labouebe G, Yvon C, Creton C, Fritschy JM, Rudolph U, Luscher C. Neural bases for addictive properties of benzodiazepines. Nature. 463:769-774. [PubMed: 20148031]

Tobler I, Kopp C, Deboer T, Rudolph U. Diazepam-induced changes in sleep: role of the alpha 1 GABA(A) receptor subtype. Proceedings of the National Academy of Sciences of the United States of America. 2001; 98:6464-6469. [PubMed: 11353839]

Tsai G, Coyle JT. Glutamatergic mechanisms in schizophrenia. Annual Review of Pharmacology \& Toxicology. 2002; 42:165-179.

Villafuerte S, Heitzeg MM, Foley S, Wendy Yau WY, Majczenko K, Zubieta JK, Zucker RABM. Impulsiveness and insula activation during reward anticipation are associated with genetic variants in GABRA2 in a family sample enriched for alcoholism. Molecular Psychiatry. 2012; 17:511-519. [PubMed: 21483437]

Vollenweider I, Smith KS, Keist R, Rudolph U. Antidepressant-like properties of alpha2- containing GABA(A) receptors. Behavioural Brain Research. 2011; 217:77-80. [PubMed: 20965216]

Wallner M, Hanchar HJ, Olsen RW. Ethanol enhances alpha 4 beta 3 delta and alpha 6 beta 3 delta gamma-aminobutyric acid type A receptors at low concentrations known to affect humans. Proceedings of the National Academy of Sciences of the United States of America. 2003; 100:15218-15223. [PubMed: 14625373]

Yamashita M, Marszalec W, Yeh JZ, Narahashi T. Effects of ethanol on tonic GABA currents in cerebellar granule cells and mammalian cells recombinantly expressing GABA(A) receptors. Journal of Pharmacology \& Experimental Therapeutics. 2006; 319:431-438. [PubMed: 16844844] 

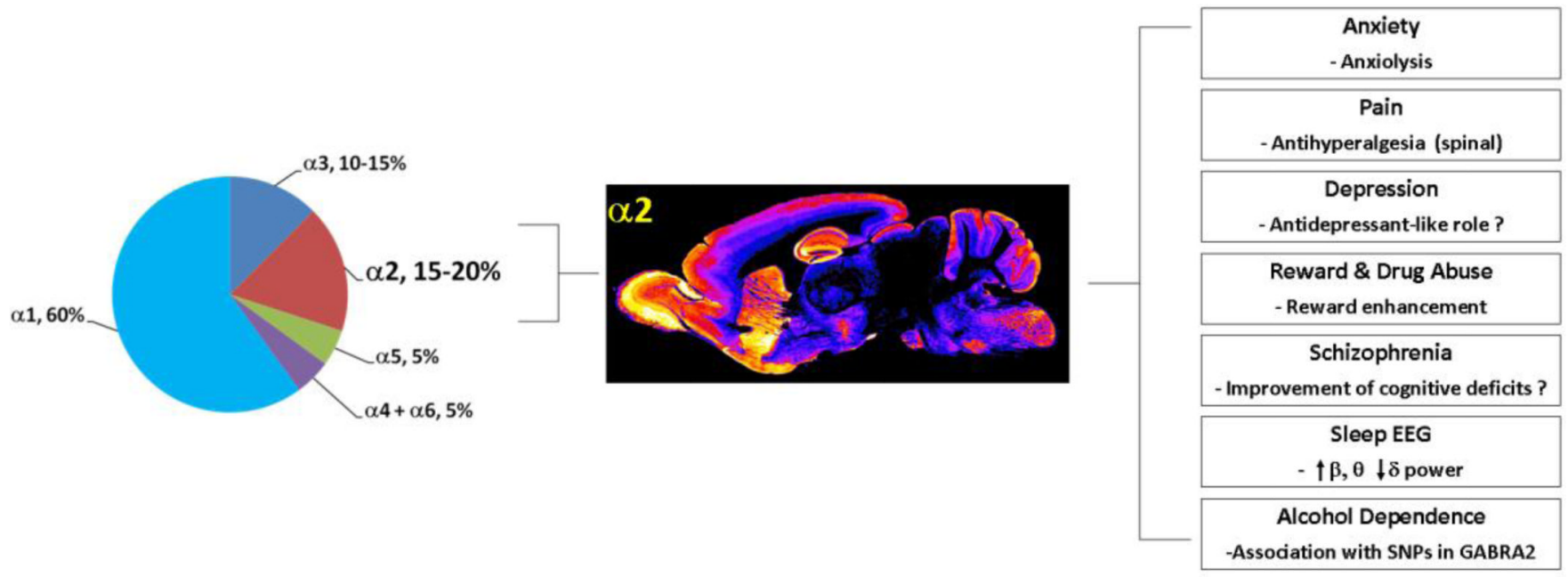

Figure 1.

Approximate abundance, distribution and functions of a2-containing $\mathrm{GABA}_{\mathrm{A}}$ receptors. Left panel: Approximate abundance of major $\mathrm{GABA}_{\mathrm{A}}$ receptor subtypes. Middle panel: Immunohistochemical distribution of the $\mathrm{GABA}_{\mathrm{A}}$ receptor a 2 subunit in a parasagittal mouse brain section (expression levels from high to low: white-yellow-red-blue). The expression of the a 2 subunit is particularly strong in hippocampus, striatum, and olfactory bulb, as well as in the amygdala (not shown). Reproduced with permission from (H. Mohler, et al., 2002). Right panel: Major functions and associations of a 2-containing $\mathrm{GABA}_{\mathrm{A}}$ receptors. The lower lines in the square represent the effects of positive allosteric modulation of a 2-containing $\mathrm{GABA}_{\mathrm{A}}$ receptors in different behavioral and physiological domains with the exception of the lowest square, where "SNPs" indicates that single nucleotide polymorphisms have been found to be assosciated with alcohol dependence. The evidence regarding antidepressant-like actions via a2-containing $\mathrm{GABA}_{\mathrm{A}}$ receptors is so far only suggestive, and the improvement of cognitive deficits in schizophrenia by allosteric modulation of a 2-containing $\mathrm{GABA}_{\mathrm{A}}$ receptors in humans is still controversial and requires further study. 

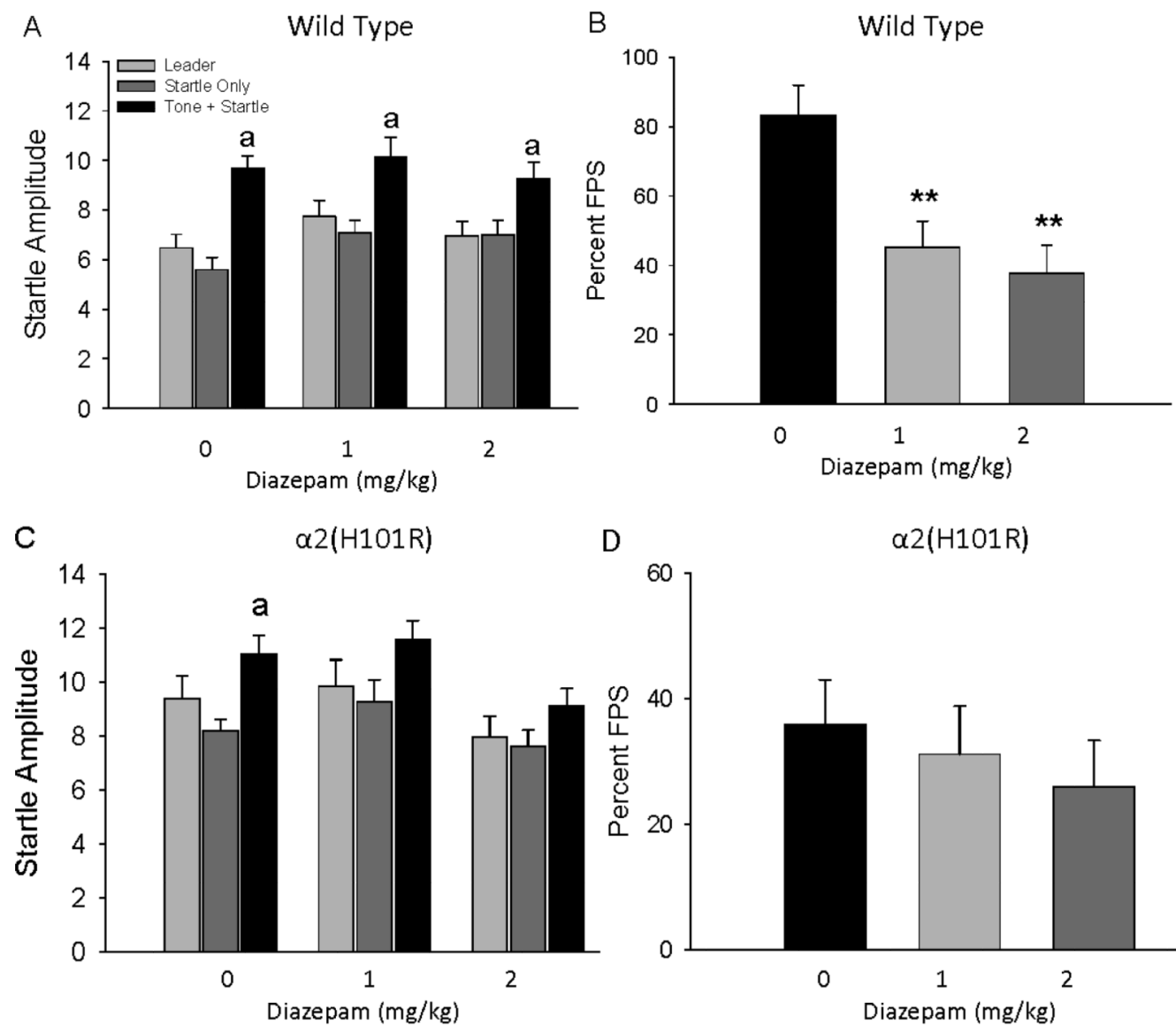

D $\quad \alpha 2(\mathrm{H} 101 \mathrm{R})$

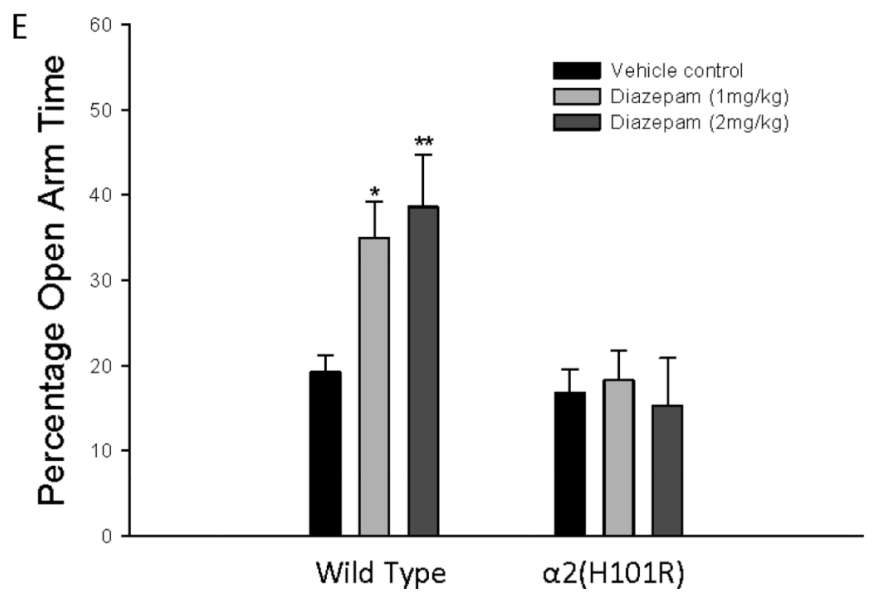

Figure 2.

Panels A-D: Impact of diazepam on conditioned fear in the fear-potentiated startle test in wild type and a2(H101R) mice. Mean startle amplitude measures in wild type (A) and a 2(H101R) (C) mice following diazepam $(0,1,2 \mathrm{mg} / \mathrm{kg})$ show that both genotypes show fear-potentiation of the baseline startle response in tone+startle stimulus trials ( a=startle amplitude on Tone+Startle trials significantly different from both Leader and Startle Only trials). Diazepam reduced percent potentiation of the startle response following fear conditioning in wild type (B) but not in a2(H101R) (D) mice. Panel E: Impact of diazepam on unconditioned anxiety in the elevated plus maze test in wild type and a2(H101R) mice. 
Percentage of time spent in the open arms was increased significantly by diazepam administration in wild type (left) but not in a2(H101R) (right) animals. *Different from the vehicle group of the animals in the same genotype at $\mathrm{p}<0.05$. **Different from the vehicle group of the animals in the same genotype at $\mathrm{p}<0.01 . \mathrm{N}=9-12$ per group. Figure modified from (K.S. Smith, et al., 2012). 
NSFT

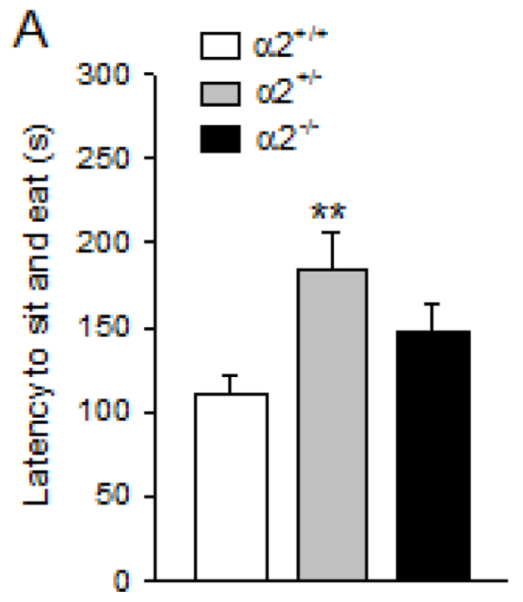

FST

B

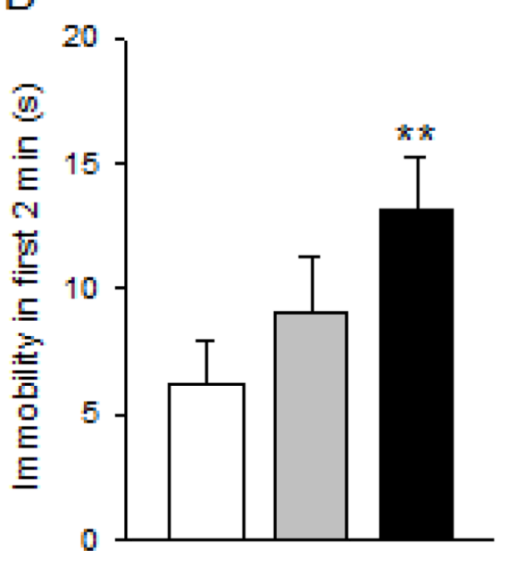

TST

C

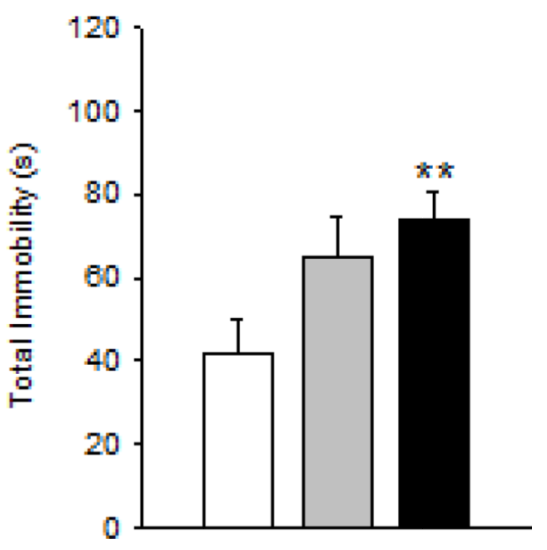

Figure 3.

Anxiety-like and depressive-like behavior of wild type mice $\left(a 2^{+/+}\right)$, and mice heterozygous $\left(\mathbf{a} 2^{+/-}\right)$and homozygous $\left(\mathbf{a} 2^{-/-}\right)$for the a 2 knockout allele. Panel A: In the noveltysuppressed feeding test (NFST), a conflict-based test assessing anxiety-like behavior, a $2^{+/-}$ mice showed greater latency to consume a food pellet in a novel environment compared to wild type mice, with the a $2^{-/-}$mice ranking in between wild type and a $2^{+/-}$. Panels B-C: In two tests of behavioral despair, the forced swim test (FST) and the tail suspension test (TST), a $2^{-l-}$ mice showed greater immobility compared to wild type mice. **Different from the wild type $\left(a 2^{+/+}\right)$group at $\mathrm{p}<0.01 . \mathrm{N}=12$ per group. Figure modified from (Vollenweider et al., 2011). 


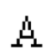

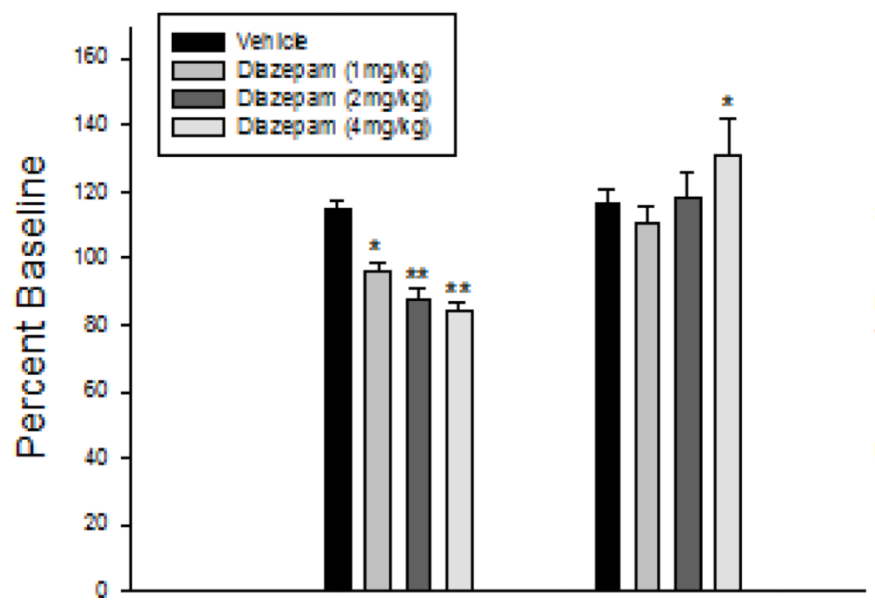

$\mathrm{B}$

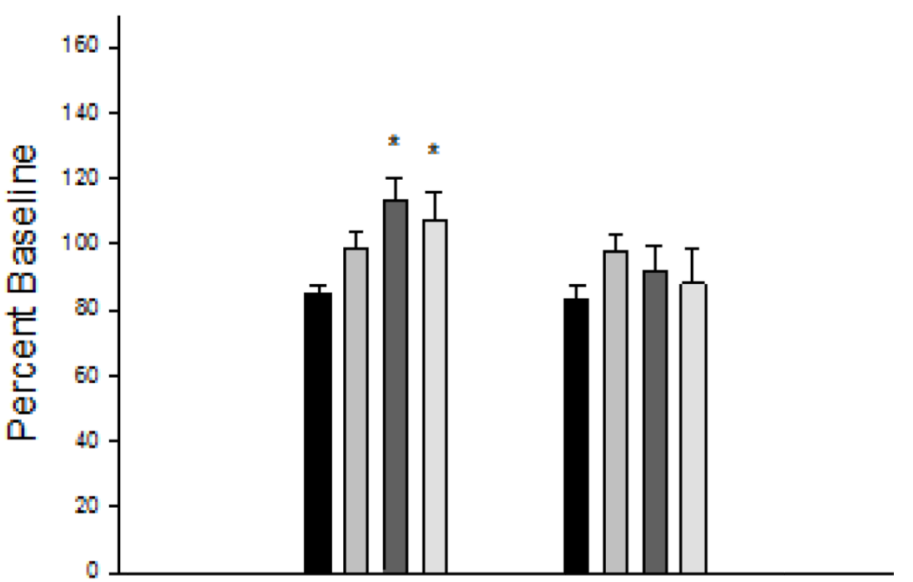

Figure 4.

Impact of diazepam on brain stimulation reward (intracranial self-stimulation, ICSS) in wild type and a2(H101R) mice. Panel A: A reduction in reward thresholds (i.e. the lowest frequency of stimulation that the animals find rewarding) is considered to be a rewardenhancing effect and is observed following the administration of drugs of abuse and other rewarding manipulations. Diazepam dose-dependently reduced reward thresholds in wild type mice, but not in a2(H101R) mice. In a2(H101R) mice, at the highest dose, diazepam even increased the reward threshold, indicating that it had aversive properties. Panel B: Diazepam did not lead to a reduction in maximum response rates in either genotype, suggesting that it was not sedative / motor impairing at the administered doses. The increase in maximum response observed in wild type mice is an artifact of the reward-enhancing effects of diazepam, and is abolished in a2(H101R) mice. *Different from the vehicle group of the animals in the same genotype at $\mathrm{p}<0.05$. **Different from the vehicle group of the animals in the same genotype at $\mathrm{p}<0.01 . \mathrm{N}=12$ per group. Figure modified from (Reynolds, et al., 2012). 